\title{
Comunicação
}

[Communication]

\section{Caracterização genotípica de amostras Escherichia coli isoladas de mastite bovina}

[Genotypic characterization of Escherichia coli isolated from cows with mastitis]

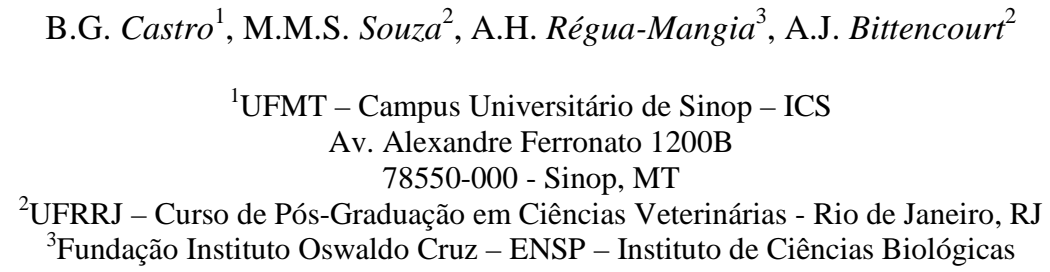

A mastite bovina é considerada a doença que acarreta grandes prejuízos à produção leiteira. Dentre os agentes causadores desta enfermidade, destaca-se a espécie Escherichia coli, descrita como um dos mais prevalentes microrganismos causadores da mastite bovina de origem ambiental (Shpigel et al., 1998).

No Brasil, são limitadas as pesquisas sobre fatores de virulência, principalmente os estudos que abordam aspectos da diversidade genética em estirpes de $E$. coli isoladas de mastite bovina (Lira et al., 2004). A E. coli Shiga-Toxigênica (STEC) é a linhagem que mais está associada à bovinocultura, pois tem sido isolada frequentemente na carne e no leite de bovinos clinicamente saudáveis (Caprioli et al., 2006). Este estudo teve como objetivo realizar a tipificação genotípica e estimar prevalência de STE em amostras de Escherichia coli, proveniente de casos de mastite bovina em municípios do estado do Rio de Janeiro.

Foram visitadas 10 propriedades rurais nos municípios de Barra Mansa e Resende, estado do Rio de Janeiro. Foram examinadas, pelo California Mastitis Test, todas as vacas em linha de ordenha, coletando-se amostras positivas para isolamento e identificação, seguindo metodologia descrita por Koneman et al. (2001). As amostras de E. coli foram comparadas genotipicamente por meio da técnica de amplificação randômica de DNA polimerase (RAPD) (Pacheco et al., 1997).
Após a etapa de isolamento e identificação da microbiota bacteriana, foram separadas as amostras de $E$. coli identificadas para análise do polimorfismo dos segmentos de DNA obtidos por amplificação randômica Random Amplification of Polymorphic DNA (RAPDPCR). As etapas de extração do DNA bacteriano, da reação dos ensaios de amplificação randômica do DNA polimórfico e da análise dos produtos da amplificação foram realizadas de acordo com o método proposto por Pacheco et al. (1997).

Para o ajuste da concentração das células bacterianas, uma alíquota de $20 \mu \mathrm{L}$ do crescimento bacteriano em caldo de tripticaseína de soja (TSB-BBL) a $37^{\circ} \mathrm{C} / 18-24$ h foi diluída a 1:10 em água destilada ou salina para determinação da densidade ótica (DO) em 600nm. Para a DO de 0.4 de absorvância, uma alíquota de $200 \mu \mathrm{L}$ foi centrifugada e ressuspendida em $900 \mu \mathrm{L}$ de água destilada estéril. A suspensão foi submetida à fervura por 10min, e o lisado bacteriano foi rapidamente centrifugado (spin) e utilizado como fonte de DNA nas reações de amplificação.

Um volume de $3 \mu \mathrm{L}$ do lisado bacteriano foi utilizado nas reações de amplificação juntamente com outros reagentes: 20mM Tris- $\mathrm{HCl}(\mathrm{pH}$ 8.4) (Fermentas, Burlington, Canadá), 50mM HCl, $4 \mathrm{mM}$ de $\mathrm{MgCl}_{2}$ (Fermentas, Burlington, Canadá), 250 $\mu \mathrm{M}$ (cada) dNTP (ABgene, Epsom, Reino Unido), 30pmol de iniciador e $1 \mathrm{U}$ Taq polimerase (Fermentas, Burlington, Canadá).

Recebido em 19 de maio de 2010

Aceito em 28 de fevereiro de 2011

E-mail: castrobg@ufmt.br 
Foram utilizados os seguintes iniciadores: 1254 (5' CCGCAGCCAA3'), M13 (5'-GAGGGTGGCGGTTCT-3'), e A04 (5'-AATCGGGCTG-3’). A reação foi programada para desnaturação inicial de $94^{\circ} \mathrm{C}$ por $1 \mathrm{~min}$; seguida de quatro ciclos de $94^{\circ} \mathrm{C}$ por $5 \mathrm{~min}, 37^{\circ} \mathrm{C}$ por $5 \mathrm{~min}$ e $72^{\circ} \mathrm{C}$ por $5 \mathrm{~min}, 30$ ciclos de $94^{\circ} \mathrm{C}$ por $1 \mathrm{~min}, 37^{\circ} \mathrm{C}$ por $1 \mathrm{~min}$ e $72^{\circ} \mathrm{C}$ por $2 \mathrm{~min}$ e, extensão final de $72^{\circ} \mathrm{C}$ por $10 \mathrm{~min}$.

A amplificação simultânea dos genes stx1, stx2 e eae, para detectar presença de STEC dentre os isolados, foi feita segundo China et al. (1996), em que as amostras de E. coli foram semeadas em $5 \mathrm{~mL}$ de Caldo Müeller Hinton (Merck) a $37^{\circ} \mathrm{C}$ por 18 a $24 \mathrm{~h}$. Após o período de incubação, $300 \mu \mathrm{L}$ da cultura foram centrifugados por 30s em microcentrífuga, e o sobrenadante foi descartado. O sedimento foi ressuspenso em $50 \mu \mathrm{L}$ de água destilada estéril e submetido à fervura por $10 \mathrm{~min}$. O lisado bacteriano foi centrifugado por 30s em microcentrífuga, e o sobrenadante coletado e usado como fonte de DNA.

Para a reação de PCR, foram utilizados $1 \mathrm{U}$ de Taq Polimerase (Fermentas, Burlington, Canadá), $5 \mu \mathrm{L}$ de $2 \mathrm{mM}$ deoxinucleotídeo trifosfato- DNTP (ABgene, Epsom, Reino Unido), $5 \mathrm{~mL}$ de tampão $10 \mathrm{X}$ buffer $(100 \mathrm{mM}$ Tris- $\mathrm{HCl}$ [pH 8.8], 15mM MgCl2, 500mM KCl, 1\% Triton X-100) (Fermentas, Burlington, Canadá), $0.5 \mathrm{~mL}$ de cada iniciador $(40 \mathrm{mM})$ (Bioneer, Seul, Coréia do Sul), e $5 \mu \mathrm{L}$ de DNA para um volume final de $50 \mu \mathrm{L}$. As reações foram realizadas em um termociclador Eppendorf Master Cycler, programado para $94^{\circ} \mathrm{C}$ por $5 \mathrm{~min}$, seguido de 30 ciclos por $94^{\circ} \mathrm{C}$ por $30 \mathrm{~s}, 50^{\circ} \mathrm{C}$ por 30 s e $72^{\circ} \mathrm{C}$ por 30 s. As amostras de E. coli E40705 (stx1 e eae positivos) e E30121 (stx2 e eae positivos) foram incluídas no estudo como controle de reação.

Os produtos da reação das amplificações foram submetidos à eletroforese em gel de agarose a $1,5 \%$. Os perfis de amplificação foram submetidos à análise visual e automatizada, com auxílio do software UVI soft image acquisition and analysis software, empregando-se o programa UVIPro bandmap versão 11.9 (UVItec, Cambridge, Reino Unido).

Os resultados revelaram que a taxa de ocorrência de mastite no leite das 273 vacas incluídas no estudo foi de 20,6\%. Dentre os agentes isolados, 14 amostras (15,2\%) foram identificadas como E. coli, sendo 13 isoladas de casos de mastite subclínica e apenas uma de caso de mastite clínica. Foram observadas amostras geneticamente relacionadas aos casos de mastite bovina. Os grupos clonais isolados da propriedade 1 representavam amostras de diferentes animais. Além destas, foi observada similaridade entre amostras das propriedades 4, 7 e 9, que compreendiam isolados distintos de uma mesma vaca.

De acordo com os resultados obtidos nos casos de mastite bovina causados por E. coli submetidas à reação em cadeia de polimerase - Multiplex (Multiplex-PCR), 14,3\% apresentavam gene para produção de toxina Shiga, sendo detectados os três genes.

Os resultados confirmam o observado por Lira et al. (2004). Esses autores verificaram incidência de 12,0\% de STEC nas amostras de leite com mastite, cujo agente etiológico era E. coli. No entanto, os mesmos autores relataram maior ocorrência de genes associados às STEC, em que metade das amostras apresentavam o gene eae, enquanto, no presente estudo, nenhuma das duas amostras apresentaram o referido gene. Este fato pode ser explicado pela maior quantidade de amostras de E. coli avaliadas por Lira et al. (2004), pois a taxa de incidência de STEC nas amostras de leite foi similar.

A observação de padrões eletroforéticos iguais entre si de amostras bacterianas isoladas de vacas de uma mesma propriedade sugere a disseminação do referido agente bacteriano no rebanho, fato que pode ser explicado pelas precárias condições higiênico-sanitárias das fazendas visitadas.

As amostras onde foram detectados os genes foram obtidas de quartos mamários distintos de uma mesma vaca, e, de acordo com o estudo molecular, são organismos com o mesmo perfil eletroforético, fato que evidencia a necessidade da constante monitorização dos rebanhos bovinos leiteiros.

Este estudo tem grande importância, principalmente, no que se refere à vigilância sanitária de produtos alimentícios, visto que é comum o consumo de leite recém-ordenhado 
pelos trabalhadores rurais, e é frequente a venda informal de leite de algumas das propriedades visitadas em mercados vizinhos. Esse fato aumenta a possibilidade de ingestão de agentes patogênicos pelo consumo desses produtos, sem o prévio tratamento térmico. Os resultados obtidos contribuem para esclarecer aspectos biogenéticos-epidemiológicos desse patógeno e fornecer subsidios para ações de monitoramento e controle dessas infecções.

Palavras-chave: vaca, mastite, Escherichia coli, STEC

\begin{abstract}
Escherichia coli samples isolated from cases of dairy mastitis in municipalities of Rio de Janeiro State, Brazil, were genotypically compared and Shiga-toxin genes were detected and their prevalence evaluated. Genetically related samples were verified and the referred genes were detected in $14.28 \%$ of the cases.
\end{abstract}

Keywords: dairy cattle, mastitis, Escherichia coli, STEC

\section{REFERÊNCIAS BIBLIOGRÁFICAS}

CAPRIOLI, A.; MORABITO, S.; SCHEUTZ, F. et al. Pathogenesis of verocytotoxin/Shiga toxinproducing Escherichia coli infection (conference summary). Emerg. Infect. Dis., v.12, 2006.

CHINA, B.; PIRSON, V.; MAINIL, J. Typing of bovine attaching and effacing Escherichia coli by multiplex in vitro amplification of virulenceassociated genes. Appl. Environ. Microbiol., v. 62, p. 3462-3465, 1996.

KONEMAN, E.W.; JANDA, S.D.; SCHRECKENBERGER, W.M. et al. Diagnóstico microbiológico. MEDSI: Rio de Janeiro, 2001. 1465p.
LIRA, W.M.; MACEDO, C.; MARIN, J.M. The incidence of Shiga toxin-producing Escherichia coli in cattle with mastitis in Brazil. J. Appl. Microbiol., v.97, p.861-866, 2004.

PACHECO, A.B.F.; GUTH, B.E.C.; SOARES, K.C.C. et al. Random amplification of polymorphic DNA reveals serotype-specific clonal clusters among enterotoxigenic Escherichia coli strains isolated from humans. J. Clinic Microbiol., v.35, p.1521-1525, 1997.

SHPIGEL, N.Y.; WINKLER, M.; ZIV, G.A. Clinical, bacteriological and epidemiological aspects of clinical mastitis in Israeli dairy herds. Prev. Vet. Med., v.35, p.1-9, 1998. 